\title{
Spelling, phonology and etymology in Hittite historical linguistics
}

\author{
Mark Weeden ${ }^{1}$ \\ School of Oriental and African Studies \\ nw41@soas.ac.uk
}

\begin{abstract}
This is a review article on Alwin Kloekhorst, Etymological Dictionary of the Hittite Inherited Lexicon (Leiden Indo-European Etymological Dictionary Series 5. Leiden and Boston: Brill, 2008. \$199. ISBN 978 900416092 7). The article addresses issues arising from Kloekhorst's depiction of Hittite cuneiform spelling conventions in the context of the wider cuneiform world (Mesopotamia and Northern Syria). In particular the representation of a glottal stop in Hittite and relevant cuneiform writing is addressed. The second part of the article addresses further individual graphic and lexical issues arising throughout the etymological dictionary.
\end{abstract}

The book under review here (Alwin Kloekhorst, Etymological Dictionary of the Hittite Inherited Lexicon (Leiden Indo-European Etymological Dictionary Series 5. Leiden and Boston: Brill, 2008, ISBN 9789004 16092 7)) is a revised version of the author's $2006 \mathrm{PhD}$ dissertation at the university of Leiden. The aim of this book is to provide as comprehensive an account as is possible of the historical phonology of Hittite, the oldest attested Indo-European language. The method used is to subject the entire lexicon inherited by the Hittites from the Indo-European mother-language to etymological analysis. In addition, sublexical morphemes such as suffixes, verbal endings and particles are similarly analysed. In the process of this analysis the author (AK) is guided by two basic methodological guidelines: the separation of linguistic elements belonging to the three different chronological layers of Hittite linguistic development, Old Hittite, Middle Hittite and New Hittite, and the strict separation of the areas of orthography, phonetics and phonology. A systematic and comprehensive account of Hittite historical phonology is thus achieved, which lends greater authority to its individual etymologies by virtue of its extensive scope and detail.

AK's work is not the first of its kind. Not only are there two separate and partially overlapping current etymological dictionary projects in Hittite studies (Tischler $H E G$; Puhvel $H E D$ ), but other monographs on Hittite historical phonology and its place within the Anatolian language family are also available (Melchert 1994, Kimball 1999). Kloekhorst criticizes the monographs for not taking all the relevant material into account, and the dictionaries for lacking a coherent view of phonological development in Hittite (p. 1). Without these collections, however, it would have been extremely difficult for AK to produce his own work, and it is not the case that they are 
superseded on every front, especially given AK's explicit defence of particular models of Hittite historical phonology that are not universally accepted.

Furthermore, the present work is restricted to those words that are deemed to be Indo-European, whereas the two ongoing etymological dictionary projects include words of non-Indo-European origin. In this regard, students at least should be wary, especially at this price, if they want to buy a Hittite-English dictionary. While we now have a dictionary of Hittite that covers all letters of the alphabet, we still do not have a detailed work that covers the whole of the Hittite language. A comprehensive dictionary was not the author's intention, however. The reader is referred to the previous dictionaries for details of the attestations of particular spellings of words. Words beginning with letters not yet covered by the dictionaries are researched using the computerized corpus of J. Tischler (p. 158).

After a general introduction to the Hittites and their script and language, the book is divided into two main sections. The first, entitled "Towards a Hittite historical grammar", presents a synoptic account of the historical phonology and significant elements of the morphology of Hittite from the author's point of view. The second part is devoted to the "Etymological dictionary of the Hittite inherited lexicon". AK stresses that neither part should be read in isolation (p. 2) and I fully agree. Throughout the etymological section the rigorously applied criterion for the correctness of an etymology is its participation in a phonological system, the whole of which will not work well if individual parts are aberrant. Similarly, the premise for the deduction of the rules of orthography, phonetics and phonology is wholly given by the etymological analyses presented in the dictionary. Everything has to work. As a further interdependence between the two sections, when reading the synoptic chapters one frequently misses references to previous opinions of other scholars, which are often provided solely by means of reference to the previous main synoptic works in Hittite historical phonology. This apparent lack is often remedied when referring to the etymological part of the work and the detailed analyses contained therein.

Not only is there a grand plan at work here as regards Hittite, AK also demonstrates an extremely confident grasp of the larger issues of Indo-European, and is not reluctant to show this early on in the work. The Indo-Hittite hypothesis, whereby the Anatolian language family broke off from Indo-European at an earlier stage than all the other Indo-European languages, is defended vigorously in the introduction (pp. 7-11), using exclusively lexical arguments which are derived from the etymological investigation in the present work. This contrasts with the largely morphological arena in which this debate is otherwise usually enacted (e.g. Lehrman 1998; Yoshida 2008).

In Part 1, "Toward a Hittite historical grammar", AK begins the chapter on Hittite historical phonology with the further basic revelation that he adheres to the glottalic theory of the reconstruction of Indo-European stops, according to which the traditional three-way articulatory split between Indo-European voiceless, voiced and aspirated voiced stops is replaced by a view that sees them as plain fortis, (pre-)glottalized lenis and plain lenis stops respectively (p. 16). This is hardly mentioned again during the work, and the traditional symbols using voiceless $\left(\right.$ e.g. $\left.{ }^{*} p\right)$, voiced $(* b)$ and voiced aspirate $\left({ }^{*} b^{\mathrm{h}}\right)$ for the 
Indo-European stop system are used as a shorthand throughout. This particular glottalic theory, deriving from F. Kortlandt (p. 16), eschews voicing and aspiration as distinctive features in Proto-Indo-European, suggesting instead that consonantal length was distinctive. This is of significance for AK's treatment of the stops in Hittite.

After a summary of the Proto-Indo-European (PIE) (1.1) and Proto-Anatolian (1.2) phoneme inventories, we are introduced to the Hittite phoneme inventory (1.3). Importantly, the notion that Hittite distinguished between voiced and voiceless stops is rejected in favour of a distinction between lenis (written single) and fortis (written double) consonants. Again the account is refreshing, with new insights and clear, incisive arguments. The picture thus presented fits very well with a reconstructed PIE glottalic stop system (p. 25). For a very different view, however, see the account in Melchert 1994, but now also Patri 2009, which uses the evidence of writings of Hittite words in other contemporary languages to try to establish the phonemic values of the Hittite stops.

\section{The glottal stop hypothesis and non-Hittite cuneiform}

Previous work by Kloekhorst, which is continued and expanded in this book, has aimed at the elucidation of a phonemic glottal stop in Hittite preserving what had been the first laryngeal. ${ }^{2}$ This is argued on orthographic and morphological grounds: contrast $u$-wa-a-tar "inspection" and wa-a-tar "water" from *Hu-ótr and *uódr respectively. A spelling such as pa-ri-pa-ra-a-i "he blows" is also taken to indicate preservation of the glottal stop /pripriâii/< ${ }^{*}$ pri-prh ${ }_{1}$-ói-ei. The fact that the vowel is always written, never *pa-ri-ip-ra-a-i, is taken as an indication that the $-r$ - has become syllabic interconsonantally. ${ }^{3}$ Using morphological arguments AK compares the writings of the strong and weak stems of ablauting verbs with root structure $\mathrm{CeC}$ and those with $\mathrm{HeC}$. $\check{s} a-\check{s} a-a n-z i$ "they sleep" / ssánt $^{\mathrm{s}} \mathrm{i}$ /, with zero-grade of the root, is morphologically parallel to the similarly zero-grade $a-\check{s} a-a n-z i$ "they are", which in this case must represent $/$ isánt $\mathrm{s} i /<* h_{1} s$-énti according to AK's account (p. 25).

Similarly, morphological arguments assert the existence of syllabic resonants which are seen reflected, for example, in the distinction between S3 $a$-ar-aš-zi /Rárst $\mathrm{s} \mathrm{i} /$ "flows" and P3 ar-ša-an-zi/Prsánt $\mathrm{i}$ //"they flow" $<* h_{1}$ érs-ti, *h $h_{1} r s$-énti, where the plene-spelling never occurs in the weak grade forms. The initial plenespellings, $a$-ar-a $\check{s}-z i$, "flows" $e-e \check{s}-z i$, "is", are asserted to represent e.g. "a real /a/ that was short" (p. 210), or simply an accented vowel, i.e. /Résti/ $<* h_{l} e ́ s-t i$ (p. 120 n. 243). By contrast it appears to be the writing with an initial vowel in the first place which indicates the presence of a glottal stop.

2 See Kloekhorst 2006. For the possible preservation of PIE $* h_{1}$ in the hieroglyphic sign á, see Kloekhorst 2004. The use of á to write $/ \mathrm{P} /$ or $/ \mathrm{K} \mathrm{a} /$ in hieroglyphic had already been recognized by Gelb (1935: 15-16). In view of the discovery of the orthographic rule of "initial a-final" in earlier hieroglyphic (Hawkins 2003: 159-61) this analysis needs to be thoroughly revised (Melchert 2010: 152-3). For the pioneering discussions on the glottal stop in Hittite see for example Sturtevant (1936: 186-7), assuming that $\mathrm{H}$ realized an inherited glottal stop $\left({ }^{*} h_{1}\right)$ in writing intervocalically, but that it was lost in other positions.

3 For a direct critique of this see Rieken (forthcoming). 
There is a risk that the argument could appear circular here. The spelling conventions are deduced from the morphology and the reconstruction of the morphology is dependent on the spelling conventions. One is also struck by the importance given to the example of $a$-ar-aš-zi "flows" vs. $a r-s ̌ a-a n-z i$ "they flow", which is mentioned numerous times and plays a key role in the establishment of the theories of both the glottal stop and the syllabic resonants. If it is indeed the case that $\# \mathrm{a}-\mathrm{aC}$ indicates /RáC/, while $\# \mathrm{aC}$ - indicates / $\mathrm{RC} /$ (p. 121) we would expect to find evidence for this in words that are not from the data set used to establish the rule, i.e. vowel-initial ablaut forms in verbs.

To avoid circularity one might adduce here occasional (mis-)writings of foreign words, for example with or without an initial $h$ : É $a$-la-an-du-wa (KUB 17.24 ii 11, unique) v. É ha-le-en-tu-wa (the usual spelling), "cultic building or palace". ${ }^{4}$ However, it is important for AK that \#ha- and \#a-represented different phonemes (see discussion of hane/išš- "wipe", pp. 285-7). In this case $a$-la-an-du-wa would have to have represented /P(a)landuwa/ according to AK's conventions, and would indicate that the scribe had misunderstood the spelling conventions or misheard the word. ${ }^{5}$

The supposed Hittite glottal stop was thus allegedly written with a V-VC-sign in the inflectional forms with full-grade root, but with a V(C)-sign in the inflectional forms with zero-grade root; $\mathrm{AK}$ is insistent that this does not amount to a vocalization of the Indo-European first laryngeal, ${ }^{*} \mathrm{~h}_{1}$. According to him $a-\mathrm{CV}$ is in fact meant to convey ' $a_{\mathrm{x}}-\mathrm{CV}$, with an empty vowel in cases where this is not required by the morphology: $a-\check{s} a-a n-z i=/ 2 \operatorname{sant}^{\mathrm{s}} \mathrm{i} /$ as $t a-r a-a n-z i=/ \operatorname{trant}^{\mathrm{s}} \mathrm{i}$ / (p. 121). Thus we arrive at a situation where \#V-VC, \#V-CV, and \#VC- can all indicate the presence of the glottal stop as part of the spelling conventions, but \#V-VC- can also indicate initial long vowels. ${ }^{6}$ This needs some further and more explicit codification as a series of spelling conventions, rather than as an explanation of a morphological model. The question also needs to be addressed as to how far any vowel-initial sign, and indeed any word-initial vowel, is not going to be pronounced with an accompanying glottalic onset. If any initial vowel has a glottalic onset, how can a glottal stop be phonemically contrastive word-initially?

To avoid the accusation of circularity one might try to demonstrate that this type of writing is typical of cuneiform more generally. As a spelling convention we would expect it to have been imported along with the writing, and thus to be in evidence for the spelling of similar sounds elsewhere in cuneiform. An alternation between a writing $\# \dot{u}$-wa- and a writing \#wa-, similar to that used to establish a pattern for the writing of a glottal stop in *Huótr vs. *uódr above, is found for example at Late Old Babylonian Alalakh, but within the same

4 It is also possible that these are different words, however $\left(\mathrm{HWb}^{2} \mathrm{~A} 56 ; \mathrm{H} 20,25\right)$. For the varied spellings of ${ }^{\mathrm{E}}$ halentuwa/halentiu see $\mathrm{HWb}^{2} \mathrm{H} 20-26$.

5 In the case of GIS allantaru (p. 169, always \#VC-) AK follows Puhvel (HED 1/2, 29) in deriving it from "Semitic" 'allān "oak" and Hitt. tāru- "wood". A Hittite language phonetic estimation involving a glottal stop is not, however, attempted.

6 The glottal stop is only taken to be indicated by $\# \mathrm{~V}(\mathrm{C})$ - spellings when an initial PIE $* \mathrm{~h}_{1}$ is supposed to be preserved as a glottal stop. In the case of $a$-an-š "he wipes" (pp. 182-3) the \#V-VC- writing is taken as indicating ānši $<* h_{2} o ́ m h_{1}-s-e i$, where the laryngeal would have been lost anyway. 
word, although not in the same text: $u$-wa-aš- $b u$ vs. $w a-(a-) a s ̌-b u(-u)$ "they remain".7 It is firstly not clear what this distinction represents in Akkadian, and secondly difficult to imagine that it represents a writing of $/ p w /$. The writing $\dot{u}$-wa- here in the stative of waša found, $u-w a-$ is used to write the D-stem of verbs I-w, mostly in Old Babylonian (OB), but occasionally later. ${ }^{8}$ This clearly has the function of marking the prefix vowel as against the prefixless stative and imperative forms. Its use in a stative in this Late Old Babylonian North Syrian text is obscure, but all evidence points against $\dot{u}$-wa- being the writing of a glottal stop.

AK twice (p. 25, notes 34 and 35) points out that Boğazköy Akkadian has been supposed to represent an alef with a V-sign, referring to Durham (1976: 109, 117). In Kloekhorst 2006: 80 he goes so far as to say that "in Akkadian ... the glottal stops could be written with the plain vowel signs when necessary", again with reference to Durham 1976. Durham (1976: 282) gives references for his statements that the sign I can be used for ${ }^{\prime} \mathrm{i}_{\mathrm{x}}$ (p. 105), $\mathrm{U}^{\prime}$ for ${ }^{\prime} \mathrm{u}_{\mathrm{x}}$ (p. 109) and $A$ for ${ }^{\prime} \mathrm{a}_{\mathrm{x}}$ (p. 117). None of these are word-initial, however (e.g. bal-țu-a KUB 1.16 i 15 iš-a-lu RS 17.237 obv. 11). ${ }^{9}$ Nor do any of these look like Hittite broken syllabification patterns (e.g. $w a-a l-a h-z i$ for $/$ walh $^{t} \mathrm{si} /$ ) for indicating an abnormal vocalization. It is common in Assyriology to accept that these writings indicate in some fashion the presence of an alef: baltu' $a$, is alu. ${ }^{10}$ However, to extrapolate from this habit of writing to the conclusion that $\mathrm{V}$-signs could equally well render phonetic ' $\mathrm{V}$ is only valid if the practice of writing ' $\mathrm{V}$ - with $\mathrm{V}$ - is also observed in initial position (see below). Otherwise it is positionally determined and will more plausibly achieve its goal of calling attention to the alef through disruption of the typical sequence $\mathrm{CV}-(\mathrm{VC})-\mathrm{CV}$ than through our positing an alternative value of $\mathrm{V}$ as ${ }^{2} \mathrm{~V} .{ }^{11}$

$7 u ́$-wa-aš-bu AlT 24, 8 (ATOB 31.05) vs. wa-aš-bu-ú AlT 20, 10 (ATOB 31.02); $w a-a s ̌-b u$ AlT 21, 7 (ATOB 31.03), ATOB 31.15, 5; wa-a-aš-bu AlT 22, 7 (ATOB 31.04) $u \check{s}-b u$ AlT 18,10 (ATOB 31.01A).

8 wu"urum "to order, send" (CAD A/2, 320-22) selection: ú-wa-'i-ra-an-ni-a-ti "he sent us" Baghdader Mitteilungen 2.56 i 13, 24; $u$-wa-e-ru-ka "I ordered you" AbB 1.56, 6; $u$-wa-e-ra-an-ni "he sent me" TCL 7.20, 6 i-wa-e-ru "they ordered" ARM 6.19, 31 vs. wu-ú-ur "he was under orders" ibid. (all OB); watārum "increase" (CAD A/1, 487-90): transitive $\dot{u}$-wa-te-er "I added" UET 6.380, 4, 10; intransitive $\dot{u}$-wa-at-tar "will become important" CT 40.17, 52, see ú-at-tar "will increase" CT 38.39, 17 (both SB Alu); $u$-wa-tar "will be more" CT 27.42 obv.(!) 18 (SB Izbu), all by contrast to stative watar, "to be more" (passim); walādum "to give birth" (CAD A/1, 288-94) $u$-wa-al-li-id "I gave birth" RA 46.90, 47 (OB) vs. (e.g.) wa-al-du "who was born" ARM 6.43, 5; id $\hat{u}$ "know": $\dot{u}$-wa-ad-di-a-am "he assigned to me" AlT 11, 7 (ATOB $20.05)$ vs. $w a-a d-d u-s ̌ i$ "that had been assigned to her" AlT 92,9 (MB).

9 See further Durham (1976: 374-8).

10 GAG $\S 5$ with reference to writings such as $i \check{s}-a-a m$ (=iš $a m)$, ǐs-ú-mu. GAG $\S 5$ further points out that syllables closed by alef will usually be written with signs from the $\mathrm{H}$

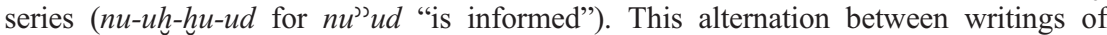
alef with or without signs from the H-series is apparently not observed in Hittite language texts.

11 In OB Akkadian we need to distinguish between various types of syllabification:

(i) a vowel sign is written medially after a VC-sign to indicate syllabic onset (ǐs-a-am);

(ii) a V-sign is written medially after a CV-sign to indicate syllabic onset with a different vowel $(i-r i-a-a b)$;

(iii) the syllable structure is broken as in iš-pur-am vs. iš-pu-ra-am (GAG §7b). 
Word-internally, Akkadian from Boğazköy did not use the specific sign for non-initial alef, ', that was introduced during the Middle Babylonian period, ${ }^{12}$ although it was used by neighbouring cuneiform cultures such as Mittani. Instead, Boğazköy Akkadian appears to have used the same sign for $/ P /$ as it used for $/ \mathrm{h} /$. Indeed, we have cases of duplicate manuscripts of the same text, one with a Boğazköy ductus and one with a Mittanian ductus, where the Boğazköy version uses the AH-sign and the Mittanian version the alef-sign: Boğazköy el-te-'é-šu-nu-[m]a "I conquered them" vs. Mittani el-te-'e-e-šú "I conquered him". ${ }^{13}$ A similar observation can be made concerning the practice of writing alef when writing Akkadograms in Hittite texts, where signs of the H-series are used: $S U$ - $U H-A-L U$ "cough". ${ }^{14}$ In neither of these cases is the writing entirely parallel to $\mathrm{OB}$ writing practice. Clearly the $\mathrm{AH}$ sign is being used in a functionally equivalent role to the alef-sign, as indeed it continued to be used sporadically in later Akkadian. For our purposes it is important that it is marked.

From the point of view of non-Hittite cuneiform theory there are three complexes here that need to be addressed for consideration of the question of a word-initial representation of alef: the initial-plene writings of the G-present and D-present and preterite conjugations of the weak verbs with initial alef (verbs $\mathrm{I}^{ }$) in the Old Babylonian dialect; the hypothesis that word-initial vowels were pronounced with a glottal stop in the first place and thus that V-signs could alternatively also be read as 'V-signs; the writing of words from local idioms in peripheral Akkadian dialects which may have influenced Hittite orthography and also may have preserved the glottal stop themselves.

Old Babylonian Akkadian has the striking orthographic feature of writing the initial syllables of verbs I-' in the G-present (and D-present and preterite) with a plene vowel: $i$-ik-ka-al or $i$-ka-al "he eats", $i$-il-la-ak "he goes" vs. $i-k u-u l$ "he ate", $i$-il-la-ak vs. $i l-l i-i k$ "he went". ${ }^{15}$ This type of writing was continued in "peripheral" Akkadian dialects after it had gone out of fashion in Middle Babylonian. ${ }^{16}$ Standard Assyriological opinion has it that this in some way

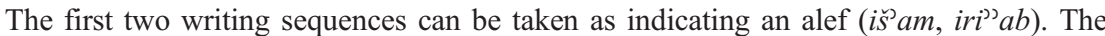
third does not. The essential function of the first two spellings is to alert the reader to the presence of something not otherwise expressed in the script through perpetrating a break in the usual spelling conventions. For Old Assyrian see Kouwenberg 2003: 77-8, especially n. 15 .

12 AkkSyll. 233; MZL 635 (considered by R. Borger to be simply a late variant of the sign MZL 636, AH).

13 Using the values 'á for AH (AkkSyll. 234) and 'a for AkkSyll. 233: el-te- 「'é-e-š $\rceil u-n u-t i$ KBo 1.1 obv. 30 (Boğazköy) // el-te-'e-e-šu-nu-ti KBo 1.2 obv. 11 (Mittani); el-te-'é-šu-nu-[m]a KBo 1.1 obv. 35 // el-te-'e-e-šú KBo 1.2 obv. 17'. The latest edition of these tablets (Wilhelm 2008b) transliterates both signs identically as -'e-. The Mittani version KBo 1.2, however, clearly differentiates between the writing of words with the phoneme $/ P /$ (AkkSyll. 233) and those with the phoneme $/ \mathrm{h} /$ (AkkSyll. 234), for which the gunated form of the sign $\mathrm{AH}$ is used exclusively. For this reason I prefer to keep the signs separate in transliteration in accord with von Soden and Röllig in AkkSyll. but against Borger in MZL.

14 KUB 8.36 ii 15', iii 2'], 6' (Bürde 1974: 38).

15 E.g. i-ik-ka-al CH §180, 57; i-ka-al TCL 7.73, 7 (OB let. CAD A/1, 253); i-il-la-ak AfO 18.65 ii 25 (CAD A/1, 309).

16 Wilhelm 1971; Kouwenberg 2003-04: 98-100. 
represents the initial alef of these verbs. ${ }^{17}$ There are good reasons for not accepting this account, as it does not explain the OB distribution in a meaningful way. ${ }^{18}$ We would also not expect a glottal stop to be at the beginning of these words in the first place. N.J.C. Kouwenberg most recently suggests understanding the G-present and prefixed D-stem forms as contracted long vowels, to be read illak, ikkal, $\hat{u} b b a b$, etc. ${ }^{19}$

Here one must also be wary of not comparing like with like, as the initial syllables of the third person of the prefix conjugations have their historical roots in prefixes beginning $y i$-(G-stem) $/ y u$-(D-stem), and writing conventions such as $i$-il- may be more plausibly derived from third millennium writing conventions which expressed this phonetically, whatever their second millennium synchronic pronunciation may have been. ${ }^{20}$ Invocation of the original $y i / y u$ - form of the prefixes will not, however, suffice as an explanation for the distribution of \#V-VCvs. \#VC- writings in these verb conjugations in $\mathrm{OB}$, as \#V-VC- is not attested as a spelling for the preterite. ${ }^{21}$

The theory invoked by AK that word-initial vowels in Akkadian can have a glottalic onset can be heard occasionally in Mesopotamian studies. ${ }^{22}$ Occasionally this theory is expressed in the form that $\mathrm{V}$-signs are essentially CV-signs with' (alef) as the consonant: thus ' $\mathrm{V}-{ }^{23}$ These are two fundamentally different ways of looking at the question, one phonological, the other orthographic. Beyond the evidence of the initial plene writings in the verbs $\mathrm{I}^{2}$ and their now dubious support for the use of \#V-VC- writings to indicate alef, it is very difficult to find anything that could help us answer the question as to the presence of a pre-vocalic glottal stop in a meaningful way. According to indications from the phenomenon of crasis as considered by N. J. C. Kouwenberg, what evidence there is suggests a split in the way the Assyrian and Babylonian dialects of Akkadian dealt with word-initial vowels. Assyrian

17 GAG §25d, §97c; Jucquois 1966: 175; Seminara 1998: 110, 345; see further literature at Kouwenberg 2003-04: 86 fn. 7.

18 Kouwenberg 2003-04: 86. The central objection is that there is a clear distribution between writings where an original alef would have originally been intervocalic (written \#V-VC- or \#V-CV-) and those where it was pre-consonantal (only written \#V-CV-). Kouwenberg's objection that we might expect a glottal stop to be written occasionally with initial plene-writing in the G-preterite $\left(i k u l<*^{3} k u l\right)$, if the \#V-VC-writing had in fact represented the alef, is not immediately comprehensible, given that it is not intervocalic in this position, whereas it is in all the others. This does not significantly affect his overall critique of the theory that alef is expressed through initial plene-writing, however.

19 One example not mentioned by Kouwenberg is the unique OB writing $a$ - $a p$-lu for regular ap-lu "have been paid" (P3m. stative) at AlT 9, 5 from Alalakh (CAD A/2, 157). It is not necessary to interpret this as marking a glottal stop, although one would have to resort to an explanation such as "hypercorrection", due to the consistent writing of the G-present of the same verb with \#V-VC- at OB Alalakh: i-ip-pa-al. For consideration of \#V-VCwritings that fall outside the ambit of the G-present and D-present/preterite of verbs I-' see Kouwenberg 2003-04: 89-90.

20 For the Sargonic ( $3^{\text {rd }}$ millennium BCE) Akkadian tendency to write \#yi- with the sign I and $\#^{\prime} i$ - with the sign İ see Hasselbach 2005. For a rejection of this as an explanation of the OB distribution of \#V-VC- writings see Kouwenberg 2003-04: 86 n. 8.

21 Kouwenberg 2003-04.

22 See literature at Kouwenberg 2003-04: 90, n. 21.

23 Lipin 1973: 46-7. 
appears to have behaved occasionally as if there were a consonantal element pre-vocalically in word-initial position, whereas Babylonian does not. ${ }^{24}$ For the purposes of AK's argument this finding is of dubious value, as it is generally agreed that the Hittites inherited cuneiform from a Babylonian writing tradition, although it has to be admitted that there are sporadic features of "Assyrian" phonology in some Hittite Akkadograms. ${ }^{25}$

Thus it appears that neither cuneiform orthography nor Akkadian phonology offer independent evidence for the patterns posited by AK for the Hittite use of cuneiform signs to represent the glottal stop. If Kouwenberg is correct in assuming that the writing $\# \mathrm{~V}-\mathrm{VC}$ - in $\mathrm{OB}$ Akkadian verbs $\mathrm{I}^{-}$represents an extra long, contracted vowel, then a significant part of the evidence is in fact negative for AK's hypothesis, and militates in favour of alternative interpretations of one of his most important examples: $a$-ar-aš-zi "flows", vs. $a r-\check{s} a-a n-z i$ "they flow". 26

Finally we need to consider evidence from the writing of non-Akkadian elements from local idioms in Akkadian peripheral cuneiform. The West Semitic languages in particular preserved phonemes that had clearly disappeared from (Babylonian) Akkadian by the Old Babylonian period. Of relevance here are the phonemes $/ /$ (alef), $/ /$ (ayin), $/ \mathrm{h} /$ (het), $/ \mathrm{h} /$ (het), $/ \mathrm{h} /$ (hey) and $/ \dot{\mathrm{g}} /$ (gayin). ${ }^{27}$ The largely contrary indications arising from Akkadian linguistic elements in cuneiform against potential expression of a glottal stop through $\mathrm{V}$ (C)- signs makes consideration of this question all the more crucial. If AK's hypothesis of the glottal stop in Hittite cuneiform stands, and there is evidence that West Semitic linguistic elements containing these phonemes showed them in cuneiform writing using similar methods to Hittite cuneiform, we would have an indication that the Hittites inherited their cuneiform writing from a West Semitic milieu. The question thus assumes an importance over and above Hittite phonology.

The most complete presentation of evidence concerning this topic for the Old Babylonian period is Streck 2000, which collects and analyses the totality of lexemes posited for the Amorite language. Most of these are attested in personal names. The evidence for the writings of the relevant phonemes in syllable-initial position is summarized in Table 1 .

24 Kouwenberg 2003-04: 91 has examples of crasis such as $a$-na-bi-ia for $a$-na a-bi-ia "to my father" in both Old Assyrian and Old Babylonian, although he observes that this is more unusual for Old Assyrian. On the other hand, Old Assyrian proclitic prepositions sometimes behave as if there was a consonant at the beginning of vowel-initial words: $a$-am-ti-šu "for his slave-girl", representing /a"amtī̌su/ from an(a) amtǐšu (AKT 3.32, 3). This is in keeping with the stronger phonemic status of alef in Assyrian by comparison to Babylonian (Kouwenberg 2003-04).

25 The frequent spelling of the Akkadian abstract formant (Babylonian) $-\bar{U} T U$ with a double -TT- as -UTTU, is supposed to be an Assyrian trait.

26 H. C. Melchert had interpreted this as representing $/ \bar{a}{ }^{2} t^{\mathrm{s}} \mathrm{i} /$ (presumably vs. /arsant ${ }^{\mathrm{s}} \mathrm{i}$ ) ) with (synchronically irregular) lengthened grade in the singular (Melchert 2004: 125).

27 Streck 2000: 231-56. The existence of the phoneme / $\mathbf{g} /$ for Amorite is not secure (ibid. 231 with Anm. 2). Although Streck reconstructs all of these Semitic phonemes for Amorite, there are circumstances under which the other consonants were all reducible to $P /$ and then subject to disappear entailing vowel contraction inter-vocalically. 
Table 1. Evidence for the writing of phonemes in syllable-initial position

\begin{tabular}{llllll}
\hline $\mathrm{h}$ & $\dot{\mathrm{g}}$ & $\mathrm{\jmath}$ & $\mathrm{h}$ & $\mathrm{h}$ & c \\
\hline $\mathrm{H}$ & $\mathrm{H}, 0^{28}$ & H, 0, V-VC- & H, 0 & H, 0 & H, 0, V-VC- \\
\hline
\end{tabular}

According to the evidence shown in Table 1, the West Semitic phoneme $P /$ can be written either with $\mathrm{H}$, with 0 (zero), or with $\mathrm{V}_{1}-\mathrm{V}_{1} \mathrm{C}$ - at the beginning of a syllable..$^{29}$ It shares this characteristic with $/ \%$. Whilst there is no discernible geographical distribution of these writings for $P /{ }^{30}$ there do appear to have been differences, possibly attributable to geography, in the writing of $/ \%{ }^{31}$ At Alalakh for example, syllable-initial // was only written using the 0 -writing, i.e. it was not written, whereas it was sometimes written using $\mathrm{H}$ when in syllable-final position. Rather than implying that // was written as ' ${ }^{\prime} a_{\mathrm{x}},{ }^{\prime}{ }^{\prime}{ }_{\mathrm{x}},{ }^{\prime} u_{\mathrm{x}}$ initially at Alalakh, this evidence could equally well be interpreted as showing that / $/$ had disappeared word-initially there in those Amorite words for which it can be reconstructed.

If the Hittite writings of vowel signs were in fact using similar methods to express the presence of a glottal stop, as were being used in cuneiform to express the phonemes of Amorite that were alien to Akkadian, we would expect there to be at least some writings with the $\mathrm{H}$-series to indicate that there was some kind of meaningful sound there. ${ }^{32}$ However, as we have seen, AK wants to keep / / / and $/ \mathrm{h} / \mathrm{h}$ phonemically distinct in Hittite, as descendants of separate Indo-European laryngeal consonants $* \mathrm{~h}_{1}$ and $* \mathrm{~h}_{2}$, the one written using solely $\mathrm{V}$-signs, the other using solely $\mathrm{H}$-signs. The alleged Hittite practice is thus not comparable to OB cuneiform's attempts to represent similar Amorite

280 (zero) in this case means allegedly writing the $\rho /$ simply with a $\mathrm{V}(\mathrm{C})$-sign at the beginning of a syllable with a CV-sign at the end of a syllable.

29 Streck 2000: 232-3. A word-initial writing with \#V-VC- is not attested, although it is attested for $\%$. Unfortunately Streck's interpretation of this evidence (p. 232 with Anm. 2) was not taken into account in Weeden 2009: 104-07, particularly n. 125, where it was argued that an alternation $\mathrm{H} / 0$ in Akkadian writings of the same names (e.g. ha-ia-vs. $a$-ia-) reflected uncertainty as to the rendering of phoneme $/ \mathrm{h} /$. The possibility that the phoneme $/ P /$ could potentially lie behind these writings should also explicitly have been mentioned in that discussion.

30 Streck 2000: 232.

31 ibid. 252.

32 One could argue that Hittite must have imported its cuneiform from a writing environment where they only used the 0 -writing for West Semitic words with alef and ayin (for example), such as Alalakh for syllable-initial writings of ayin. This assumes the conclusion one is trying to prove and is thus not greatly useful as evidence. It may be the case, however, that some foreign words with guttural consonants were rendered in Hittite either with $\mathrm{H}-$ or V-, as we saw above for ${ }^{\mathrm{E}} a-l a-a n-d u$-wa vs. ${ }^{\mathrm{E}}$ ha-le-en-tu-wa, thus resorting to exactly the same tactics as cuneiform from neighbouring areas. I am unaware of further cases, and considerable caution is urged given divergent opinions on the relationship between the two words ( $\mathrm{HWb}^{2}$ loc. cit.). For a decided opinion on the representation of the Egyptian phoneme / $\mathrm{h} /$ as Hittite H see Simon 2009: 345-6. Simon 2010 now attempts to demonstrate the validity of Kloekhorst's theory of the glottal stop for initial plene-writings in Cuneiform Luwian. A central plank of the argument stems from the assumption that hieroglyphic Luwian á represents $\mathrm{Pa}$, a position that is severely vitiated by the new evidence of "initial a-final" (see fn.2). 
phonemes in general, although it may be partially comparable to the specific case of the writing for word-initial / $/$ at Alalakh VII.

AK pleads for a very strong version of the interpretation of $\# \mathrm{~V}$ - signs as $\#^{3} \mathrm{~V}$ signs, assuming as he does that they share the feature of Hittite CV- signs which allows them to have a silent vowel in consonant clusters. This requires a considerable re-thinking of basic categories: we have a vowel sign in which the vowel can be silent, because it is in fact a CV-sign. The case of the \#VCsign which is in fact not a VC-sign, because it indicates the presence of a glottal stop without a vowel, is also very difficult to accommodate within any theory of cuneiform spelling. Essentially this is like saying that $\# \mathrm{VC}-={ }^{2} \mathrm{VC}$ (i.e. $\mathrm{C}_{1} \mathrm{VC}_{2}$ ) and that the middle vowel can be silent.

The next question is whether AK's interpretation of the internal Hittite, Anatolian and Indo-European evidence for the expression of a glottal stop in Hittite cuneiform can have repercussions for the debates in non-Hittite cuneiform studies about the expression of the glottal stop in the writing and its presence before word-initial vowels in Akkadian phonology. The usefulness of his proposal for our understanding of cuneiform outside of Anatolia thus rests entirely on whether the glottal stop can definitely be established for Hittite as a phoneme in initial position and whether we can seriously say that this is represented in the writing. To address this on a linguistic level would require a far more extensive treatment of all posited examples than is possible in the present article and is also beyond the competence of the reviewer. ${ }^{33}$

The economy of AK's model is very beguiling. It allows us to reconstruct verbal ablaut paradigms for Hittite that fit what we suppose to have been the case in the Indo-European proto-language very closely: / $2 e s-t^{s} i /, / 2 s$-ant $t^{s} i /<$ $* \mathrm{~h}_{1}$ és-ti, * $\mathrm{h}_{1} \mathrm{~s}$-ónti, "is, are". Unfortunately it involves doing significant violence to our usual conception of the way in which the cuneiform script works, and for this reason it is difficult to accept.

\section{Further phonological issues: $u / o$ and $\mathrm{i} / \mathrm{e}$}

A large amount of space is devoted to the meticulous treatment of the signs $U$ and U' (pp. 35-60). The upshot of this systematic presentation of all phonetic contexts in which the signs occur, together with the relevant spellings of the words, is that Hittite orthography does indeed indicate an /o/-phoneme, represented on a limited basis by the sign $-u$-, versus an $/ \mathrm{u} /$-phoneme represented by the sign $-\dot{u}-$. Attestations are sifted carefully according to tablet palaeography and stage of linguistic development displayed by the text. Thus AK is able to conclude for example that the "diphthong/au/ is lowered to /ao/ before $n$ from Middle Hittite times onwards". Here, however, one must now be extremely careful, especially in light of the current re-evaluation of the relationship between Old and Middle Hittite palaeography (e.g. Popko 2005, 2007; van den Hout 2009). A simple equation of an "Old Script" palaeography and "Old Hittite times", or "Middle Hittite palaeography" and "Middle Hittite

33 Rieken (forthcoming) addresses this issue. My thanks are due to E. Rieken for allowing me to see her review before publication. 
times" (p. 44) is no longer possible. Here it may perhaps in future be necessary to conduct further analysis, including a specification of other linguistic forms present on a tablet and their particular stadial categorization, in order to supplement the purely script-based assessment of a form's age according to its occurrence on a tablet with a particular script type. A good starting point for such work was provided by H. C. Melchert's 1977 dissertation.

The use of the sign - $\mathrm{u}$ - in certain contexts to represent /o/ can of course be supplemented by evidence from Hurrian writing practices, where it is reasonably clear that the $-u$ - sign was used to represent an /o/-phoneme. ${ }^{34}$ Here again, I think it is important to stress that the Hittites were not just adapting the cuneiform script for their own purposes in a vacuum, but using the possibilities offered them by the script as they inherited it and as it was used by their neighbours.

The section on epenthetic vowels, pp. 60-61, though short, is also of fundamental importance for AK's understanding of Hittite phonology. It involves the development of three epenthetic vowels in separate phonetic environments. As one of these AK posits a vowel of intermediate quality between /i/ and /e/ which arises in clusters involving /s/ with a stop or laryngeal and can be written either as -i- or as -e-. This deals with a good number of the tricky Hittite variant writings that sometimes spell the same word with either -i- or -e- vocalism. Many further examples of words showing such alternation in spelling are explained later on (pp. 92-3) as the result of a lowering of $\mathrm{OH} / \mathrm{i} /$ to $\mathrm{NH} / \mathrm{e} /$ before $/ \mathrm{s} /, / \mathrm{n} /$ and $/ \mathrm{m} /$ and clusters involving $/ \mathrm{H} /(-l h$ - and $-t h-)$. Although stubborn counter-examples remain (e.g. inan-, innara-, n. 201) this is a comprehensive rule that explains very many different writings of the same words.

The above-mentioned points illustrate the comprehensive and systematic nature of AK's treatment of Hittite phonology, even if the system thus arrived at does not always receive support from cuneiform writing practices outside of Anatolia.

\section{Etymology}

The largest part of the work is taken up by the etymological dictionary. The layout is easy to use, with a handy collection of the spellings and their dates and the reconstructed PIE preforms at the beginning of each lemma. In a useful innovation $\mathrm{AK}$ consistently uses photos and drawings made from photos to demonstrate whether a word is correctly reconstructed from its attestations. The systematic and strict application of the rules of sound change and spelling that are laid out in chapter 1 mean that we lose many an old favourite etymology, as does the precise and thorough philological approach. The old connection of Hitt. henk-, "bestow, allot", and Gk. ananke "necessity, fate" (Pedersen 1938), is disposed of effectively on pp. 268-71 by application of philological principles. The word is honestly left without etymology. Similarly we must do without Hitt. karp- "lift, take away" being related to Skt. grabh- "to grab" (p. 455).

The issue of completeness, which was given such prominence in the introduction, will doubtless give critics much to carp about, as will AK's avowedly subjective criteria for selecting some of the lemmata. Despite the fact that a huge 
number of inherited and non-inherited lexical items are presented, one dearly misses a list of the words that were not included in the dictionary, possibly with some explanation of why in each case. A few words I did not find while using the dictionary and where I missed an explanation were alsant- "captive", huwala- "owl", ilessar, ilisni "rank", ilas, ilanas "step", kikla- "grass", kurkurima- "intimidation", lu(m)pasti- "disgrace".

The omission of the noun aliyas, aliyan(an), aliyanas "deer", which shows the typical Hittite inherited declensional pattern exhibited by nom. haras, acc. haranan, gen. haranas "eagle", seems like a missed opportunity. ${ }^{35}$ Using AK's own spelling hypothesis it might have been possible to read this phonetically as /Pliyas/, /Pliyanan/<*Hlei-ōn-s, *Hlei-on-m.. A connection with Gk. léōn, léontos, dat. pl. leiousi, "lion" and related words would have appeared phonetically plausible. ${ }^{36}$ A semantic shift of this type, presumably from "deer" to "lion", would not be entirely unparalleled among nouns denoting wild animals, although the traditional parade example of IE *wl ${ }^{*}{ }^{\mathrm{w}} \mathrm{O}$ - "wolf" > Luw. walwi- "lion" suffers under AK's analysis (see below). Given the above-mentioned doubts concerning AK's hypothesis that $\# \mathrm{~V}-=$ ?V $=$ ?, I am hesitant to advance this etymology. Without AK's spelling hypothesis the etymology is in fact impossible. ${ }^{37}$

Besides losing a number of etymologies, application of the phonological rules outlined in chapter 1 means that we also win many more etymologies, and even also the identification of previously troublesome Hittite words. The Hittite word for "woman", which is always written logographically (eg. nom. MUNUS- $a n-z a$, gen. MUNUS-na-aš) has long been a subject of discussion. Using the Hittite phonetic complements and the other Anatolian forms (CLuw. wānā-, HLuw. wanati-) AK posits an n-stem with nominative ${ }^{*} k^{w} a n t^{s}$, gen. *kwanas. ${ }^{38}$ Usually *-ns\# becomes Hittite $-s \#$, as in other common gender $\mathrm{n}$-stems like haras "eagle" from * $\mathrm{h}_{3}$ ér-ōn-s. This problem is neatly side-stepped by the extension of the rule that medial $*$-nHs- $>-n z-\left(*^{*}\right.$ genh ${ }_{1}$-su- $>$ genzu"loin") to final syllables as well as to medial ones: ${ }^{*}-n H s \#>-n t$.

Support for this as the reading of the Hittite word for "woman" comes from the excavations at Ortaköy. On a widely attested hieroglyphic seal-impression kindly shown to me by Professor A. Süel, whom I thank for the permission to mention this here prior to publication, we read BONUS $_{2}$ FEMINA REL-a-zi/a BONUS 2 FEMINA, "good woman, Kwa(n)z(a), good woman".

35 Attestations: nom. $a$-li-ia-aš KBo 32.14 obv. ii 3 (MH/MS); KUB 14.1 rev. 91 (MH/MS) acc. $\lceil a\rceil-l i-i a-a n$, KUB 14.1 rev. 92; acc. a-li-ia-n[a-an] KBo 32.14 obv. ii 1; a-li-ia-na-an ibid. obv. ii 12; gen. a-li-ia-na-aš KBo 32.14 obv. ii 17 (not necessarily for nom., cf. Neu 1996: 116); gen. for nom. KBo 32.14 obv. ii 26 (Neu 1996: 128 explains the asyntactic gen. as the scribe changing his mind about the syntactic structure after starting the sentence).

36 Admittedly an explanation would need to be found for the lack of \#e/a/o- in Greek, the so-called "prothetic vowel" (Rix 1976: 69).

37 I am informed by an anonymous reader for $B S O A S$ that a plausible derivation has been found for this word by N. Oettinger, in E. Tichy, Indogermanisches Nomen, Bremen 2003, 141-5. Unfortunately, I have not had access to this book.

38 This form had also been reconstructed for the nominative by Hardarson 1987: 118-22, although with a different paradigmatic inflection. The understanding of the said inflectional category has now been demonstrated to have been based on a since superseded etymology (Hitt. sumanza $\neq$ Greek humén). 
The seal-impression is attested multiply at least on one stopper-shaped clay object on display in Çorum Museum, as well as on a number of further objects. J. D. Hawkins suggests (personal communication) that the central name is indeed the Hittite word for "woman", thus "Mrs Woman". Although in hieroglyphic writing, this lends striking support for the shape of the word as justified in AK's discussion.

The book has indeed to be taken as a whole. As such it will be almost impossible for anyone to criticize AK's phonological system without producing their own grand scheme and comprehensive overview. In $1994 \mathrm{H}$. C. Melchert started the process of discussing Hittite and Anatolian historical phonology in global terms, in which single items are to be explained as part of an integral system. With this book AK has taken that process to a new level; he also provides us with countless good insights and analyses of individual philological and linguistic details. It is only natural that a major work such as this should excite controversy in the process of furthering discussion. The following very minor critical points in no way detract from my overall extremely positive evaluation of the book's contribution to scholarship, and emanate from my personal experience of using the book as an Assyriologist specializing in Hittite. Hittitology is for ever divided into those who approach it from the cuneiform perspective and those who approach it from the Indo-European perspective. Especially within the constraints of a modern $\mathrm{PhD}$ programme, no one can know or research everything, even if $\mathrm{AK}$ time and again shows himself to be an outstanding cuneiform philologist.

\section{Minor points of detail}

pp. 70-75: Regarding the fricative /s/ see the contemporary evidence from Ugarit for the pronunciation of the sound written with the S-series in Hittite as an interdental fricative, something like English th (now Hoffner and Melchert 2008: 38; Patri 2009).

p. 43: KBo 3.60 is characterized as being palaeographically "undated", but belongs to the palaeographic category IIIc (NSc, or Late New Script), previously held to be introduced during the reign of Tudhaliya IV, but, as argued in my 2007 dissertation, most likely to have been introduced at least by the reign of Muwatalli II (early 13th c. BC).

p. 51: The common Hittite writing $h u-u$ - is discounted from the assessment of $\mathrm{Cu}-u^{-}=$phonetic $/ \mathrm{o} /$, on the grounds that it is a "ligature" designed to distinguish the sign from the similarly shaped -RI-. This interesting idea is unfortunately unverifiable. Compare the suggestion to explain MÁŠ́, "family" (only in Hittite cuneiform), as a development from MUD, in its occasional first millennium lexical correspondence to Akkadian walādu "give birth", by subtraction of one vertical (Forrer 1926: 161; Pringle 1993: 78). The proposal to read $h u+u$ as HÚ should be avoided not only due to interference with the more general cuneiform notation, ${ }^{39}$ but also because this should be marked as a ligature, if that is what it is, for which purpose the plus sign is adequate.

39 See MZL p. 62 no. 87 for the possible but questionable phonetic value hú for $\mathrm{KU}_{4}(=$ TU) on the basis of MSL 3.25, 162. 
p. 225: Sumerographic A.A.MU is in fact "my father" (Sumerian a-a.ĝ $\left.\mathrm{u}_{10}\right)$, not just "father"; p. 261: some discussion of the alleged connection between Hitt. ésri- "shape, image, statue", and HLuwian atri- "self, soul" was expected; p. 302: the oracle-bird MUŠEN harrani- cannot be read *hurrani- due to the logographic writing ${ }^{\text {MUŠEN }}$ KASKAL, which must be based on the Akkadian reading of Sumerian kaskal: harrānu (Hoffner 1967: 23); p. 316: UR.MAH is Sumerographic for "lion" not "bear" (Sumerographic AZ), cf. correctly p. 951; pp. 323-4: I missed a mention of Melchert 1973 in the discussion of hassa hanzassa.

pp. 336-7: KAL-ga- for hatuk-, "be terrible", hatuga- "fear, terror" is more likely to be KALAG.GA, as the Sumerogram only occurs with this "phonetic complement" (-ga-) in this position, which is an unusual place to start phonetic complementation in a word. Far more likely the GA is part of the Sumerogram. Beside GA KALAG.GA, "yoghurt", lit. "strong milk", this Sumerogram is attested standing in for UR.SAG "hero" in royal titulary, (KUB 21.38 obv. 55).

p. 344: the Sumerographic use of KI.LAM for Hittite É hilammar "gatehouse" is a pseudo-Sumerographic usage based on the similarity in sound between the Sumerian and the Hittite, and cannot be used as evidence for the Hittite being a loanword from the Sumerian (Singer 1975: 94-5). It is a rebus writing. The Sumerian ki.lam is equivalent to Akkadian mahīru "market rate" (CAD M/1, 92 ) and has nothing to do with gatehouses.

p. 346: É NA $\mathrm{NA}_{4}$, "house of stone", is not the logographic equivalent of É histā, "cult building connected with the royal death-cult", due to its being partially phonetically written in Old Script Hittite in the form $\mathrm{NA}_{4}$-an pár-na-aš "(of the) house of stones" (KBo 17.15 rev.' 12; Groddek 2001: 214 f.); p. 372: the HLuw. word hurnali- "hunter" belongs here (Hawkins 2000: 512); p. 404: Akk. $M \bar{U} \breve{S} U$ (AHw. 687a); p. 412: a mention and discussion of istamahura"ear-ring" would have been very welcome in the discussion of istaman“ear"; p. 408: iš-pár-ri-ez-zi (KUB 14.1 rev. 91, the subject being a deer) almost certainly belongs here under isparra- ${ }^{i}$ /isparr- "trample", and not under ispa $\bar{r}{ }^{-}{ }^{i}$ । ispar- "spread out".

p. 420: $M A \breve{S} K U$ is cited as an Akkadogram for Hitt. idālu- "evil". To avoid possible confusion I would point out that the meaning of Akkadian mašku is "skin" (AHw. 627b). Akk. masku means "evil" and occurs only once at Hattusa in a vocabulary tablet, spelled $m a-a s ̌-k u$ (KBo 1.30, 16). This writing is due to the different realization of the $\breve{S}$ series of signs at Hattusa, and often in peripheral Akkadian to that current in Mesopotamia in the second millennium BC. Furthermore, it is not best practice to take an equivalence garnered only from a lexical list as an Akkadographic equivalent of a Hittite word. "Akkadographic" refers only to uses of Akkadian words to represent Hittite ones in continuous text. The occurrence of $m a-a \check{s}-k u$ in a lexical list is not Akkadography, but Akkadian translation.

p. 422: the putative word itar, "road", long associated with Latin iter, has now been demonstrated to be a ghost-word, to be read DUMU-tar (Miller 2008: 209, n. 97). This confirms AK's reservations about its "lenis" consonant, contrasting with LÚ ittaranni- "runner".

p. 430: the Sumerogram for "festival" at Hattusa is always EZEN 4 (EZENx ŠE), never EZEN, the usual Mesopotamian form. 
p. 446: I do not think that HLuwian ${ }^{\mathrm{CORNU}_{s u}}+r a / i$-sa/sá (KARATEPE $1 \S 6$, 36) meaning "plenty" and CORNU $\grave{u}+r a / i-n i$ meaning "horns" are the same word. The former is possibly derived from the root *suH- "full" with the suffix -ro-, perhaps united by a "Caland" suffix system to Hittite $s \bar{u} u$-/sūwau-, (<*suH-u-?) "full" (p. 794) and suwāru- (<*suH-óru-) "full, complete" (p. 796). They both use CORNU as determinative because of their similarity in sound.

p. 466: s.v. kattu- "hostility", the form kad-du-ut (instr. sg.) is also attested (KUB 43.60 obv. i 17). Mention of possibly related HLuwian forms kati, katuna was missed (Morpurgo-Davies 1986: 129 ff., 132 f., 142); p. 517: the regular Akkadian and Hittite Akkadogram for "name" is $\check{S} U M U$ not $\check{S} U M M U$; p. 566: if we dismiss a Hittite stem mad- "to withstand", in favour of maz- "id.", mention should none the less be made of the suggestion to derive Luwian maryaninzi from *mad-, implying, if it is correct, separate stem-formation in Hittite and Luwian (Schwemer 1996); p. 603: Akk. $\breve{S} A M \hat{U}$ not $\breve{S} A M \bar{U}$; p. 613: Akkadian nom. I $\check{S} \bar{A} T U$ not $I \check{S} \bar{A} T I$; p. 618: cf. Melchert's derivation of HLuw. paza- from a different root (Melchert 2004); p. 618 the transliteration of KBo 21.1 i 15 as $p a-a k-k u-u \check{s}-s ̌$ ! $-w a-a n$ on the basis of the hand-copy writing the putative $\breve{S U}^{!}$as $\lceil\mathrm{TA}\rceil$ rather than as $\lceil\breve{\mathrm{S} A}\rceil$ (with $\mathrm{CHD}$ ) is not epigraphically convincing; p. 635: against parhu- as a possible word for "fish", see Berman and Hoffner 1980, 669-70: the repeated assertion that the postulated connection between the IE verbal root *pes- "to rub", and the words Skt. pásas- "penis", Gk. péos, Lat. pénis, "does not seem semantically self-evident" to the author is not comprehensible to the reviewer; p. 700: it is unfortunate that the occasional \#z- in sakkar "excrement" and sama(n)kur- "beard" are explained by false analysis of the ending of a preceding pronoun that Hittite did not inherit: *tod skór, *tod smókur; p. 708: "U hartagga- is a "bearman" not a "wolfman" (cf. p. 316); p. $709 R A B \hat{U}$; p. 753: the status of the hapax siyant- in NINDA si-ia-an-ta(-x?) at KUB 14.3 ii 62 , whether noun or verb, is very insecure. For further suggestions see Heinhold-Krahmer et al., forthcoming.

p. 763: the reconstruction of a thematic stem Hitt. *siuna- "god" is not immediately supported by a reconsideration of the evidence.

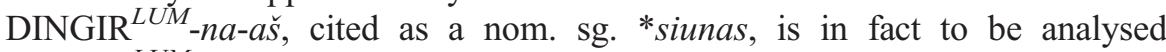
DINGIR $^{L U M}=$ nas, "Oh god, to us ..." (van den Hout 1998: 196, 224-5). The evidence of the acc. sg. siunan is also not unambiguous - this could also be a remodelling by analogy with the n-stems: sius, siun, siunas $>$ sius, siunan, siunas, like haras, haranan, haranas "eagle", and aliyas, aliyan(an), aliyanas "deer". This would also provide a motivation for the acc. sg. by-form siwanan. The existence of the i-stem *siuni- is also not entirely secured by the evidence. Why is it always DINGIR ${ }^{L I M}$-iš and never ${ }^{*} \operatorname{DINGIR}^{L U M}$-iš if the use of the phonetic complement $-i \check{S}$ is not determined by the preceding $L I M / L \grave{I}$, and thus a purely graphic phenomenon (argued in Weeden 2007: 154-8)? By contrast, DINGIR $^{L U M}$ nom.-acc. without Hittite phonetic complement is attested over 830 times. The balance of evidence makes it imprudent in my view to posit a stem * siuni- solely on the basis of only two relatively secure attestations of DINGIR-iš (KUB 31.64 obv. i 16; KUB 33.94, 6).

p. 765: the new interpretation of siwanzanna- as participial siwanz-anna"divine mother" instead of as a genitive with syncope from *siwantas anna- 
"mother of god" forgets to mention the corresponding Sumerogram MUNUS AMA DINGIR $^{\text {LIM }}$, which is clearly "mother of god". Occasional writings such as MUNUS.MEŠ DINGIR AMA could support either interpretation. ${ }^{40}$

p. 775: I GAL GEŠTIN at KUB 43.23 rev. 56 is "one cup of wine", not "one head of the wine"; p. 776 that the earth is "fixed" in place with cables is not a strange concept in Mesopotamian cosmology, thus "fixed" is perhaps not such an objectionable translation of suhmili; pp. 914-5: see the main discussion of the ethnic suffix -umen- at Melchert 1983.

p. 951: doubts concerning the equivalence Luwian walwi-= Sumerographic UR.MAH "lion" should also address the evidence of the alternating LÚ.MEŠ UR.MAḦ, "lion-men" and LÚ.MEŠ walwalla- (Otten 1969). Proponents of the equation and its additional derivation from IE *wlk ${ }^{\mathrm{w}} \mathrm{O}-$ " "wolf" (Lehrman 1989) also need to consider AK's point that PIE - * $\mathrm{k}^{\mathrm{w}}$ - is kept in Luwian, so that the second $/ w /$ in walwi- would need at the least to come from a $* / \mathrm{g}^{\mathrm{w}} /$.

\section{Abbreviations}

AHw.

AkkSyll.

GAG

HED

HEG

MSL

MZL
Akkadisches Handwörterbuch. W. von Soden.

Das Akkadische Syllabar, Analecta Orientalia 42, Rome, 1976.

Grundriss der akkadischen Grammatik. W. von Soden, third edition. Rome, 1995.

J. Puhvel, Hittite Etymological Dictionary Vol. 1: Words beginning with A, Vol. 2: Words beginning with E and I, Amsterdam 1984; Vol. 3: Words beginnning with H, Berlin 1991; Vol. 4: Words beginning with K; Vol. 5: Words beginning with L. Berlin, 2001.

J. L. Tischler, Hethitisches etymlogisches Glossar Teil I, A-K, Innsbruck 1977-83; Teil 2, L-N, Innsbruck 1990-91; Teil 3, T-D, Innsbruck 1991-94; Teil II Lief. 11/12 P, Innsbruck 2001; Teil II/2 Lief. 13: S/1.

Materials for the Sumerian Lexicon.

Mesopotamisches Zeichenlexikon, R. Borger, AOAT 305, Münster, 2004.

\section{Bibliography}

Berman, H. and H. A. Hoffner. 1980. "Why parhu- is not the Hittite word for "fish", Journal of Cuneiform Studies 32, 48-9.

Bürde, C. 1974. Hethitische medizinische Texte. (Studien zu den Boğazköy-Texten 19.) Wiesbaden.

Durham, J. W. 1976. "Studies in Boğazköy Akkadian", PhD Thesis, Harvard University. Forrer, E. O. 1926. Forschungen 1. Band 1. Heft: Die Arzaova-Länder. Berlin.

Gelb, I. J. 1935. Hittite Hieroglyphs II. (SAOC 14.) Chicago. 
Groddek, D. 2001. “'Mausoleum' (É.NA4) und 'Totentempel' im Hethitischen”, Ugarit-Forschungen 33, 213-18.

Hardarson, J. A. 1987. "Das uridg. Wort für 'Frau", Münchener Studien zur Sprachwissenschaft 48, 115-37.

Hasselbach, R. 2005. Sargonic Akkadian. A Historical and Comparative Study of the Syllabic Texts. Wiesbaden.

Hawkins, J. D. 2000. Corpus of Hieroglyphic Luwian Inscriptions. Volume I. Inscriptions of the Iron Age. Berlin.

Hawkins, J. D. 2003. "Scripts and texts", in H. C. Melchert (ed.), The Luwians. Leiden: Brill, 128-65.

Heinhold-Krahmer, S., J. D. Hawkins, J. Hazenbos, J. L. Miller, E. Rieken and M. Weeden. Forthcoming. Der Tawagalawa-Brief, oder die Beschwerden gegen Piyamaradu, to appear in the series Texte der Hethiter.

Hoffner, H. A. 1967. “An English-Hittite glossary”, Revue Hittite et Asianique 25/80, 6-99.

Hoffner, H. A. and H. C. Melchert. 2008. A Grammar of the Hittite Language. (Languages of the Ancient Near East.) Winona Lake, IN: Eisenbrauns.

Hout, Th. van den. 1998. The Purity of Kingship. An Edition of CTH 569 and Related Hittite Oracle Inquiries of Tuthaliya IV. Leiden, Boston and Cologne: Brill.

Hout, Th. van den. 2009. "A century of Hittite text dating and the origins of the Hittite cuneiform script”, Incontri Linguistici 32, 2009, 11-34.

Jucquois, G. 1966: Phonétique comparée des dialectes moyen-babyloniennes du nord et de l'est. Louvain: Institut Orientaliste.

Kimball, S. 1999. Hittite Historical Phonology. Innsbruck: Institut für Sprachwissenschaft der Universität Innsbruck.

Kloekhorst, A. 2004. "The preservation of $* \mathrm{~h}_{1}$ in Hieroglyphic Luwian: two separate a-signs", Historische Sprachforschung 117, 26-49.

Kloekhorst, A. 2006. "Initial laryngeals in Anatolian", Zeitschrift für vergleichende Sprachforschung 119, 77-108.

Kouwenberg, N. J. C. 2003. "Evidence for post-glottalized consonants in Assyrian", Journal of Cuneiform Studies 55, 75-86.

Kouwenberg, N. J. C. 2003-04. "Initial plene writing and the conjugation of the first weak verbs in Akkadian", in Jaarbericht "Ex Oriente Lux" 38, 83-103.

Lehrman, A. 1989. "Anatolian cognates of the Proto-Indo-European word for "wolf", in Die Sprache 33/1, 13-18.

Lehrman, A. 1998. Indo-Hittite Redux. Studies in Anatolian and Indo-European Verb Morphology. Moscow.

Lipin, L.A. 1973. The Akkadian Language. Leningrad.

Melchert, H. C. 1973. "Hittite hašša-, hanzašša-", in Revue Hittite et Asianique 31, 57-70.

Melchert, H. C. 1977. “Ablative and instrumental in Hittite”, PhD Dissertation, Harvard University.

Melchert, H. C. 1983. "A 'new' PIE *men Suffix”, Sprache 29, 1-26.

Melchert, H. C. 1994. Anatolian Historical Phonology. (Leiden Studies in IndoEuropean 3.) Amsterdam and Atlanta.

Melchert, H. C. 2004. "A Luwian dedication”, in J. H. W. Penney (ed.), Indo-European Perspectives. Studies in Honour of Anna Morpurgo Davies. Oxford.

Miller, J. L. 2008. "Ein Ritual zur Reinigung eines Hauswesens durch eine Beschwörung an die Unterirdischen (CTH 446)", Orakel, Rituale und Beschwörungen, Texte aus der Umwelt des alten Testaments. (Neue Folge Band 4.) Omina, (ed. B. Jankowski und G. Wilhelm), Gütersloh, 206-17. 
Morpurgo Davies, A. 1986. "Fighting, ploughing and the Karkamiš kings", in A. Etter (ed.), O-o-pe-ro-si, Festschrift für Ernst Risch zum 75.-en Geburtstag. Berlin and New York, 129-45.

Neu, E. 1996. Das hurritische Epos der Freilassung Bd. 1. Untersuchungen zu einem hurritisch-hethitischen Textensemble aus Hattuša. (StBoT 32.) Wiesbaden.

Otten, H. 1969. "Noch einmal hethitisch Löwe", Welt des Orients 5, 94-5.

Patri, S. 2009. "La perception des consonnes hittites dans les langues étrangères au XIIIe siècle", Zeitschrift für Assyriologie und vorderasiatische Archäologie 99, 87-126.

Pedersen, H. 1938. Hittitisch und die anderen indoeuropäischen Sprachen. Copenhagen.

Popko, M. 2005. "Einige Bemerkungen zum alt- und mittelhethitischen Duktus", Rocznik Orientalistyczny T. VIII Z. 2, 2005, 9-13.

Popko, M. 2007. "Althethitisch? Zu den Datierungsfragen in der Hethitologie", in D. Groddek and M. Zorman (eds), Tabularia Hethaeorum. Beiträge Silvin Košak zum 65. Geburtstag. (DBH 25.) Wiesbaden, 575-82.

Pringle, J. M. 1993. "Hittite kinship and marriage. a study based on the cuneiform texts from $2^{\text {nd }}$ millennium Boğazköy". PhD Thesis, School of Oriental and African Studies, London.

Rieken, E. forthcoming. Review of A. Kloekhorst, Etymological Dictionary of the Hittite Inherited Lexicon, to appear in Kratylos.

Rix, H. 1976. Historische Grammatik des Griechischen, Laut-und Formenlehre. Darmstadt.

Schwemer, D. 1996. "Hethitisch mad- 'widerstehen' und hieroglyphen-luwisch mariianinzi 'Rebellen' in der Karatepe-Inschrift', Welt des Orients 27, 30-35.

Seminara, S. 1998. L'accadico di Emar. (Materiali per il vocabulario sumerico, 6.) Rome.

Simon, Z. 2009. "Kann Armā mit Haremhab gleichgesetzt werden?", Altorientalische Forschungen 36/2, 340-48.

Simon, Z. 2010. "Das problem der phonetischen Interpretation der anlautenden scriptio plena in keilschriftluwischen", in L. Kogan, N. Koslova, S. Loesov and S. Tishchenko, Proceedings of the $53^{e}$ Rencontrve Assyriologique Internationale, 1/1. Language in the Ancient Near East. Winona Lake: Eisenbrauns, 249-65.

Singer, I. 1975. "Hittite hilammar and hieroglyphic Luwian *hilana", Zeitschrift für Assyriologie und vorderasiatische Archäologie 65, 69-103.

Streck, M. P. 2000. Das amurritische Onomastikon der altbabylonischen Zeit. Band 1. Die Amurriter. Die onomastische Forschung. Orthographie und Phonologie. Nominalmorphologie. (AOAT 271/1.) Münster.

Sturtevant, E. H. 1936. "Some Hittite etymologies”, Language 12/3 (Jul.-Sept.), 181-7.

Weeden, M. 2007. "Hittite logograms, studies in their origin and distribution", $\mathrm{PhD}$ thesis, SOAS, London.

Weeden, M. 2009. "The Akkadian words for 'grain' and the god Haya", Welt des Orients 39, 88-117.

Wilhelm, G. 1971. "Eine altbabylonische Graphik im Hurro-Akkadischen", Ugarit-Forschungen 3, 285-9.

Wilhelm, G. 2008a. "Hurrian", in R. D. Woodard (ed.), The Ancient Languages of Asia Minor. Cambridge.

Wilhelm, G. 2008b. Der Vertrag Šuppiluliumas I. von Hatti mit Šattiwazza von Mittani (CTH 51.I), at www.hethport.uni-wuerzburg.de/txhet_svh.

Yoshida, K. 2008. "Another archaic linguistic creature in Hittite", in A. Archi and R. Francia (eds), 6HitCongr2, Studi nmicenei ed egeo-anatolici 50, 851-9. 